\title{
Transformation of Corn Stalk Residue to Humus-Like Substances during Solid-State Fermentation
}

\author{
Yinan Yang ${ }^{1,2}$, Lili Wang ${ }^{3, *}$, Yifeng Zhang ${ }^{1}$, Libo Li ${ }^{1}$, Xuyang Shi ${ }^{4}$, Xintong Liu ${ }^{4}$, \\ Xiaodong Ren ${ }^{4}$ and Sen Dou ${ }^{1, *}$ \\ 1 College of Resource and Environmental Science, Jilin Agricultural University, Changchun 130118, China; \\ yinanyang@jlau.edu.cn (Y.Y.); yifengzhang@jlau.edu.cn (Y.Z.); bobobo1663@live.com (L.L.) \\ 2 College of Horticulture, Jilin Agricultural University, Changchun 130118, China \\ 3 School of Life Science, Anhui University, Hefei 230601, China \\ 4 School of Life Science, Jilin University, Changchun 130012, China; xyshi15@mails.jlu.edu.cn (X.S.); \\ xintong116@mails.jlu.edu.cn (X.L.); renxiaodong@jlu.edu.cn (X.R.) \\ * Correspondence: wang_lili@ahu.edu.cn (L.W.); dousen@jlau.edu.cn (S.D.); Tel.: +86-1575-512-4312 (L.W.); \\ $+86-1350-448-6204$ (S.D.)
}

Received: 24 October 2019; Accepted: 26 November 2019; Published: 29 November 2019

\begin{abstract}
Lignocellulase production from straw fermentation has been widely investigated but the research has neglected to quantify fermentation-derived residue transformation to the humus-like substance (HULIS). To investigate the conversion efficacy of corn stalk residue to HULIS, the amount of HULIS associated with chemical composition and structural changes of humic acid-like substances (HAL) was investigated in a $30 \mathrm{~L}$ solid-state fermentation tank during a short period of eight days. The results show that the highest decomposition rate of corn stalk and the highest activity of cellulase, xylanase, and $\beta$-glucosidase appeared at the fourth day. At the end of fermenting process, the amount of humic acid-like substances (HAL) and the percentage of HAL in humus acid (PQ value) increased $17.5 \%$ and $8.9 \%$, respectively, indicating Trichoderma reesei facilitates the transformation of corn stalk residue to HAL. Fatty acids decreased while aromatic carbon and carboxyl content significantly increased during the ongoing fermentation, which had a positive impact on the HAL thermal stability. The FTIR spectral and thermal analysis revealed an improvement in HAL degrees of condensation, oxidation, and aromatization. The present study suggests that the residue of corn stalks fermented with $T$. reesei might be a good fertilizer to improve soil characteristics.
\end{abstract}

Keywords: corn stalk residue; humic-like substance (HULIS); solid-state fermentation; Trichoderma reesei (T. reesei); humification

\section{Introduction}

Proper management of crop residues is becoming more critical due to its high correlation with increased crop production. In some developing countries, crop residues are usually burned in the open field, resulting in emissions of particles and hazardous gases inducing serious air pollution [1]. For preventing air pollution caused by the direct combustion of crop residues, many local governments and farmers are seeking alternative treatments. To solve the straw surplus problem, crop residues have been treated for the production of bioenergy and environmentally friendly materials [2,3]. However, due to the high reluctant content of cellulose $(25 \%-35 \%)$, hemicellulose $(20 \%-40 \%)$, and lignin $(10 \%-25 \%)$ in crop residues, an effective pretreatment method is usually required in the conversion process. Monomicrobial fermentation or physicochemical microbial methods have been widely used to pretreat crop residues due to their low cost and high environmental benefits [4-6]. A number of studies attempted to use filamentous fungi (Aspergillus, Penicillium, or Trichoderma) to produce 
high concentrations of lignocellulases from crop residues [7-10]. Cellulase is a multicomponent enzyme system that plays a synergistic role in degrading cellulose and contains endocelluloase, exoglucanase, and $\beta$-glucosidase. Endocellulase cleaves internal glycosidic bonds; exoglucanase cuts the cellulose chain from either the reducing or nonreducing end; and $\beta$-glucosidase completes the final step of hydrolyzing cellubiose to produce glucose [11,12]. T. reesei is a mesophilic, filamentous fungus, which is a major industrial source of cellulase due to its easier culture and excellent capacity for degrading various substrates into lignocellulase and cellulase, such as horticultural waste [13], stalks [14], and apple pomace [15]. The optimal fermenting conditions of T. reesei in the biodegradation of various substrates could be different, for example, a pH of 5.0-6.6 and water content of $70 \%-94 \%$ for wheat bran [16] and 4\% sodium hydroxide pretreatment for wheat stalks [17]. The highest cellulase activity was observed in $25-30{ }^{\circ} \mathrm{C}$ and a water content of $55 \%-70 \%$ when fermented rice bran with T. reesei [18].

As stated above, many studies have focused on cellulase or lignocellulase production rates from various substrates, functional mechanism of enzymes, and the optimal fermenting conditions. However, the incorporation of fermentation-derived residues in the humus-like substance (HULIS) is not completely understood. HULIS is mainly composed of humic acid-like substances (HAL), fulvic acid-like substances (FAL), and humin-like substances (HML), with similar physicochemical properties to natural soil humus, which are well known for their contribution to soil fertility $[19,20]$. The amount, the chemical composition, and the structural features of fermentation-derived HULIS are still ambiguous, despite its potential in facilitating the agricultural ecological cycle.

This study aimed to investigate conversion efficacy of fermentation residues to HULIS, considering the impacts of $T$. reesei on corn stalk degradation. The cellulose and lignin content were compared along with the cellulase, xylanase, and $\beta$-glucosidase activity. Additionally, the dynamic changes of HULIS in terms of elemental composition and structural characteristics were determined by elemental analysis, thermogravimetric analysis, and infrared spectroscopy.

\section{Materials and Methods}

\subsection{Strains and Medium}

T. reesei (MCG77), strain purchased from American Type Culture Collection (ATCC), were inoculated on a medium containing $30 \mathrm{~mL}$ potato dextrose agar (PDA) and placed in an incubator at $28^{\circ} \mathrm{C}$ for 72 hours to obtain mature mycelia; then, $2 \mathrm{~mL}$ of sterile water was added and oscillated at $130 \mathrm{rpm}$ for $2 \mathrm{~min}$. The solution was removed, placed in a sterile test tube, and diluted immediately after the oscillation. It was counted afterward by a hemocytometer plate to make a spore suspension of $10^{7}$ unit per $\mathrm{mL}$. A total of $20 \mathrm{~mL} \times 3$ of the diluted solution was transferred to a liquid medium, considering a 1:10 ratio, and then cultured for 6 days at $30{ }^{\circ} \mathrm{C}$ at $100 \mathrm{rpm}$ to obtain the stock (total $600 \mathrm{~mL}$ ) containing benton mycelium.

\subsection{Organic Materials}

The corn stalks were collected at Jilin Agricultural University experimental farm, naturally air-dried, then crushed to $0.5 \mathrm{~cm}$ in length, and stored in a sealed container. Basic properties of the corn stalk were $419.34 \mathrm{~g} \mathrm{~kg}^{-1}$ total organic carbon (TOC), $6.91 \mathrm{~g} \mathrm{~kg}^{-1}$ total nitrogen, $7.70 \mathrm{~g} \mathrm{~kg}^{-1}$ total phosphorus, $4.50 \mathrm{~g} \mathrm{~kg}^{-1}$ total potassium, and a $\mathrm{C} / \mathrm{N}$ ratio of 61 .

\subsection{Experimental Design}

The experiment was performed in a solid-state fermentation tank (Baoxing BIOTECH-30SS, Shanghai) of $30 \mathrm{~L}$, able to automatically stir materials and control humidity $(60 \%)$ and temperature $\left(30{ }^{\circ} \mathrm{C}\right)$. Fermentation speed was set at $6.0 \mathrm{rpm}$. Inorganic mineral salt was added for T. reesei's nutrition and was made up by urea $4.2 \mathrm{~g} \mathrm{~L}^{-1}$, ammonium sulfate $19.6 \mathrm{~g} \mathrm{~L}^{-1}$, calcium chloride $0.028 \mathrm{~g} \mathrm{~L}^{-1}$, potassium 
dihydrogen phosphate $28 \mathrm{~g} \mathrm{~L}^{-1}$, magnesium sulfate $4.2 \mathrm{~g} \mathrm{~L}^{-1}$, ferrous sulfate $0.07 \mathrm{~g} \mathrm{~L}^{-1}$, manganese sulfate $0.021 \mathrm{~g} \mathrm{~L}^{-1}$, zinc sulfate $0.019 \mathrm{~g} \mathrm{~L}^{-1}$, and yeast extract $7 \mathrm{~g} \mathrm{~L}^{-1}$, with an adjusted $\mathrm{pH}$ of 5 .

In total, $1.5 \mathrm{~kg}$ of crushed corn stalks were added to the fermentation tank and sterilized at $121^{\circ} \mathrm{C}$ for 1 hour. After the temperature dropping to the set temperature $\left(30^{\circ} \mathrm{C}\right), 600 \mathrm{~mL}$ T. reesei stock and $3.75 \mathrm{~L}$ sterile inorganic mineral salt were added. A round of fermentation was 8 days and 3 rounds were repeated. A treatment of corn stalk without adding T. reesei was set as control, denoted as T0. Three phases of fermented materials with $T$. reesei were sampled for 2, 4, and 8 days, denoted as T1, T2, and T3, respectively. Samples were collected after every $24 \mathrm{~h}$ period. All samples were stored at $-20^{\circ} \mathrm{C}$.

\subsection{Determination of Cellulose, Lignin, and Enzyme Activity}

The cellulose and lignin contents were analyzed and calculated based on previous reported methods [21].

A $6 \mathrm{~cm}$ Whatman filter paper (width $1 \mathrm{~cm}$ ) was folded and put into a sterile test tube. One milliliter citrate buffer $(\mathrm{pH} 4.8)$ was added in the tube with $0.5 \mathrm{~mL}$ diluted spore suspension in five series: $0.04,0.05,0.067,0.1$, and $0.2 \mathrm{~g} \mathrm{~mL}^{-1}$. After reacting at $50{ }^{\circ} \mathrm{C}$ for $60 \mathrm{~min}, 3 \mathrm{~mL}$ 3,5-dinitrosalicylic acid (DNS) was added, the mixture was heated in a boiling water bath for $5 \mathrm{~min}$, then cooled immediately. Subsequently, $200 \mu \mathrm{L}$ of above solutions were diluted with $2.5 \mathrm{~mL}$ deionized (DI) water. Absorbance values were measured on visible spectrophotometer (SP-722E) with optical density at 540 $\mathrm{nm}$ (OD 540). The ratio of 0.37, corresponding to the enzyme concentration that released $2 \mathrm{mg}$ glucose, was defined as the cellulose activity [22].

One gram of xylan was dissolved into $80 \mathrm{~mL} 50 \mathrm{mM}$ citrate buffer, stabilized in a $60{ }^{\circ} \mathrm{C}$ water bath for 1 hour, and then transferred to another water bath at $100{ }^{\circ} \mathrm{C}$ until boiling. Absorbance was measured on OD 540. The amount of enzyme to produce $1 \mu \mathrm{mol}$ xylose per minute was defined as one unit of xylanase activity [23].

A total of $200 \mu \mathrm{L}$ fermented sample solution was diluted 1:200 with citrate buffer ( $\mathrm{pH} 4.8$ ). Then, $1 \mathrm{~mL}$ of the above solution and $1 \mathrm{~mL} 15 \mathrm{mmol} / \mathrm{L}$ cellobiose were pipetted into a sterile centrifuge tube, placed in a $50{ }^{\circ} \mathrm{C}$ water bath for $30 \mathrm{~min}$, and then transferred to $100{ }^{\circ} \mathrm{C}$ water bath for 5 minutes. The tube was removed and cooled. The mixed solution was used to measure glucose content with a glucose kit (Huili Biotech, China). Another $1 \mathrm{~mL}$ of diluted sample solution and $1 \mathrm{~mL}$ of citrate buffer were added into a sterile centrifuge tube as an enzyme blank. The ratio of 0.0926 , corresponding to the enzyme concentration in $1 \mathrm{mg} / \mathrm{ml}$ of the glucose content in the sample, was defined as the activity of the glycosidase [24].The ratio of 0.0926 , corresponding to the enzyme concentration in $1 \mathrm{mg} / \mathrm{ml}$ of glucose content in the sample, was defined as the activity of the glycosidase [24].

\subsection{Extraction and Determination of Humus}

We weighed $0.25 \mathrm{~g}$ of dried $\left(55^{\circ} \mathrm{C}\right.$ for $6 \mathrm{~h}$ ) and fine ground corn stalk (passed through a sieve with $0.25 \mathrm{~mm}$ in diameter). Extraction protocol was based on the modified method of soil humus composition [25]. HULIS was extracted from corn stalk and mixed $0.1 \mathrm{~mol} \cdot \mathrm{L}^{-1}$ sodium hydroxide and $0.1 \mathrm{~mol} \cdot \mathrm{L}^{-1}$ sodium pyrophosphate. HAL and FAL were separated with $0.5 \mathrm{~mol} \cdot \mathrm{L}^{-1}$ sulfuric acid. Residues left were considered as HML. Carbon content of each component was determined according to the potassium dichromate volumetric method. The percentage of HAL in humus acid ( $P Q$ value) was calculated to evaluate the dynamic changes between FAL and HAL and measure the corn stalk humification degree [26], which is displayed as:

$$
P Q=\frac{H A L\left(g \cdot \mathrm{kg}^{-1}\right)}{H A L\left(g \cdot \mathrm{kg}^{-1}\right)+F A L\left(g \cdot \mathrm{kg}^{-1}\right)} \times 100 \%
$$

where HAL and FAL denote humic acid-like and fulvic acid-like substances, respectively, extracted from fermented corn stalk residue. 


\subsection{Purification and Determination of $H A L$}

Corn stalk samples were dissolved in $0.1 \mathrm{~mol} \cdot \mathrm{L}^{-1}$ hydrochloric acid with a ratio (solid to liquid) 1:10 $(\mathrm{V}: \mathrm{V})$. Then, $0.1 \mathrm{~mol} \cdot \mathrm{L}^{-1}$ sodium hydroxide was added and the $\mathrm{pH}$ of the mixed solution was acidified by $6 \mathrm{~mol} \cdot \mathrm{L}^{-1}$ hydrochloric acid to 1.5 to get rough HAL. The purified HAL samples were obtained by high-speed centrifugation, electrodialysis, rotary evaporation, and lyophilization, as recommended by the International Humic Substances Society (IHSS) [27]. HAL elemental composition was measured by the Vario EL III elemental analyzer (Elementar, German) in $\mathrm{C} / \mathrm{H} / \mathrm{N}$ mode. Freeze-dried HAL was analyzed for functionalization on an AVATAR 360 Fourier transform infrared spectrometer (FTIR, Nicolet, America); and the differential thermal analysis (DTA) and thermogravimetric analysis (TG) were performed by STA 2500 thermogravimetric analyzer (Netzsch, German).

\subsection{Data Processing}

Data were collected and analyzed by Graphpad Prism 6.0. One-way analysis of variance (ANOVA) and Pearson correlation with two tailed analysis were used to determine the difference and correlation of corn stalk quantitative and structural change after fermentation. All statistical tests were evaluated at the $95 \%$ confidence level.

\section{Results}

\subsection{Quantitative Change of Corn Stalk}

The quantitative change of corn stalk is ascribed to the change of material weight; TOC; cumulative degradation rate of lignin and cellulose; and enzyme activities of cellulase, xylanase, and $\beta$-glucosidase. There was approximately $9.83 \%$ stalk loss during the first three days, and about $25.09 \%$ loss in the following five days. TOC decreased $39.66 \%$ during the fermentation and the degradation rate reached the highest at the fourth day (Figure 1a). The cumulative degradation rate of lignin and cellulose revealed a sharpened increase tendency in the last four days (Figure 1b).

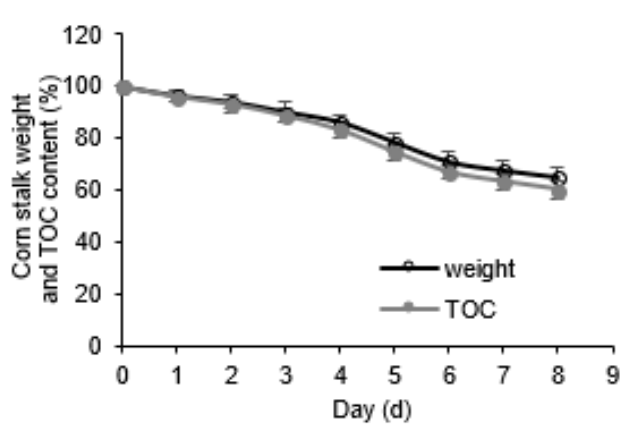

(a)

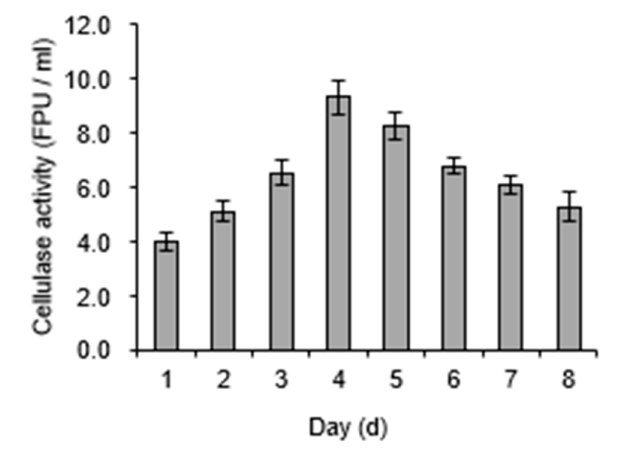

(c)

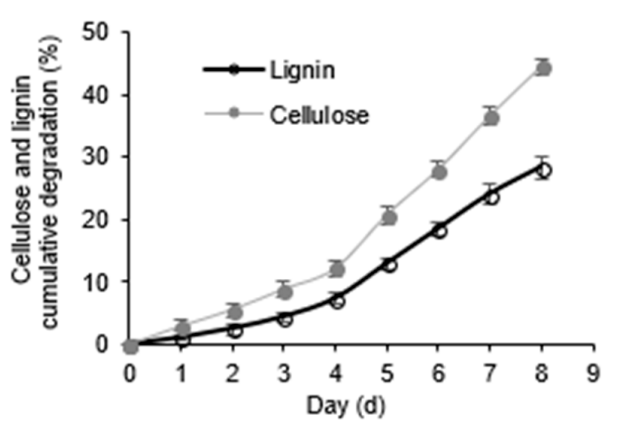

(b)

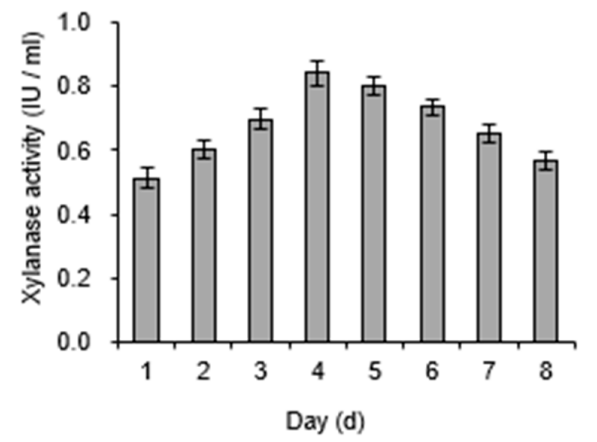

(d)

Figure 1. Cont. 


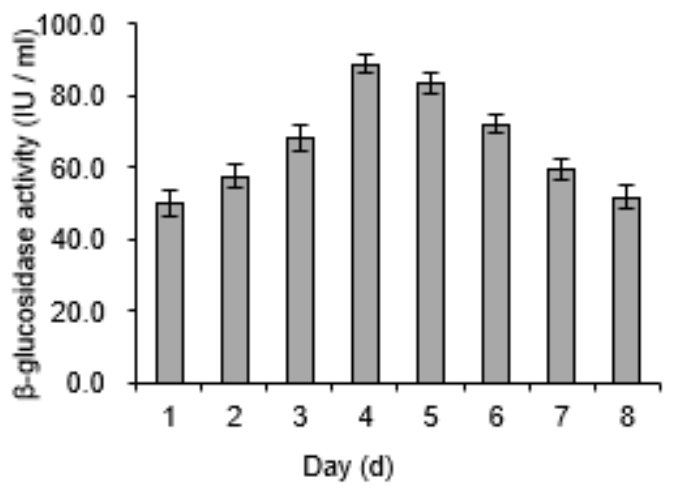

(e)

Figure 1. Quantitative change of corn stalk and enzyme activities at different fermentation times. (a) weight and total organic carbon (TOC); (b) cellulose and lignin; (c) cellulase; (d) xylanase; (e) $\beta$-glucosidase. Data represent the mean \pm SEM of triplicate.

After eight days fermentation, the cumulative degradation rate of cellulose and lignin arrived at $43.84 \%$ and $30.85 \%$, respectively. $\beta$-glucosidase showed a higher enzyme activity of $88.91 \mathrm{IU} / \mathrm{m}$ on the fourth day (Figure 1e), while xylanase had the lowest enzyme activity with $0.84 \mathrm{IU} / \mathrm{mL}$, as shown in Figure 1d. A high level of $\beta$-glucosidase was considered as a strong inhibitor of endocellulase and exoglucanase to regulate the conversion of cellulose to glucose [12].

\subsection{HULIS Composition and Transformation}

Compared to T0, the carbon content of HAL with the T. reesei treatment increased by $17.5 \%$ at the end of the fermenting process (Table 1), the C content of FAL and HML decreased by $5.54 \%$ and $7.38 \%$, and the $P Q$ value increased by $8.9 \%$, suggesting that either the formation rate of HAL was greater than FAL, or FAL degradation rate was higher than HAL. Thus, the addition of $T$. reesei to the fermentation process enhanced the degree of humification of corn stalk.

Table 1. Effects of $T$. reesei on composition and percentage of humic acid-like substances (HAL) in humus acid $(P Q)$ value of corn stalk humus.

\begin{tabular}{|c|c|c|c|c|c|}
\hline Treatment & Day (d) & $\begin{array}{c}\mathrm{HAL}^{2} \\
\left(\mathrm{~g} \cdot \mathrm{kg}^{-1}\right)\end{array}$ & $\begin{array}{c}\text { FAL }^{2} \\
\left(\mathrm{~g} \cdot \mathrm{kg}^{-1}\right)\end{array}$ & $\begin{array}{l}\text { HML }^{2} \\
\left(\mathrm{~g} \cdot \mathrm{kg}^{-1}\right)\end{array}$ & $\begin{array}{c}P Q^{3} \\
(\%)\end{array}$ \\
\hline T0 ${ }^{1}$ & 0 & $50.63 \pm 0.44 \mathrm{~d}$ & $36.08 \pm 0.07 a$ & $269.25 \pm 0.10 \mathrm{a}$ & $58.39 \pm 0.25 \mathrm{~d}$ \\
\hline $\mathrm{T} 1^{1}$ & $1-2$ & $55.70 \pm 0.07 c$ & $35.98 \pm 0.18 a$ & $268.88 \pm 0.15 b$ & $60.75 \pm 0.11 b c$ \\
\hline $\mathrm{T} 2^{1}$ & $4-5$ & $57.10 \pm 0.48 b$ & $35.16 \pm 0.08 b$ & $256.72 \pm 0.15 c$ & $61.89 \pm 0.18 \mathrm{ab}$ \\
\hline $\mathrm{T}^{1}$ & $7-8$ & $59.47 \pm 0.13 a$ & $34.09 \pm 0.07 c$ & $249.39 \pm 0.28 \mathrm{~d}$ & $63.56 \pm 0.10 a$ \\
\hline
\end{tabular}

Note: One-way analysis of variance (ANOVA) was used to determine the difference in the corn stalk composition. Multiple comparisons between every two treatments were performed using the least significant difference (LSD). Different lower-case letters in the same column mean significant difference at $p<0.05$ level; ${ }^{1} \mathrm{~T} 0$ was a control treatment of corn stalk without added T. reesei; $\mathrm{T} 1, \mathrm{~T} 2$, and $\mathrm{T} 3$ were three phases of fermented materials with $T$. reesei sampled in 2, 4, and 8 days, respectively; ${ }^{2} \mathrm{HAL}$, FAL, and HML represent three substances that, like humic acid, fulvic acid, and humin, derived from fermented straw residue, respectively; ${ }^{3} P Q=[H A L /(H A L+F A L)] \times 100 \%$.

\subsection{Elemental Composition of HAL}

The elemental composition of HAL is used to evaluate the structural change of HAL molecules and provide information of humus-like formation. The molecular structure of HAL is characterized by the molecular ratio of $(\mathrm{O}+\mathrm{S}) / \mathrm{C}$ and $\mathrm{H} / \mathrm{C}$. A higher ratio of $(\mathrm{O}+\mathrm{S}) / \mathrm{C}$ indicates more oxygen-containing groups in $\mathrm{HAL}$; conversely a lower $\mathrm{H} / \mathrm{C}$ ratio suggests a higher degree of aromatization and condensation [28].

The elemental composition of HAL is shown in Table 2. Compared to T0, the ratio of HAL (O + S)/C increased by $32.71 \%$. H/C ratio was lower than $\mathrm{T} 0$, decreasing by $5.53 \%$ by the end of fermentation. 
Table 2. Effect of T. reesei on the elemental composition of HAL in corn stalk.

\begin{tabular}{|c|c|c|c|c|c|c|c|}
\hline Treatment & $\begin{array}{c}\mathrm{C} \\
\left(\mathrm{g} \mathrm{kg}^{-1}\right)\end{array}$ & $\begin{array}{c}N \\
\left(g^{-1} g^{-1}\right)\end{array}$ & $\begin{array}{c}\mathrm{H} \\
\left(\mathrm{g} \mathrm{kg}^{-1}\right)\end{array}$ & $\begin{array}{c}\mathrm{O}+\mathrm{S} \\
\left(\mathrm{g} \mathrm{kg}^{-1}\right)\end{array}$ & $\mathrm{C} / \mathrm{N}$ & $\begin{array}{l}(\mathrm{O}+ \\
\mathrm{S}) / \mathrm{C}\end{array}$ & $\mathrm{H} / \mathrm{C}$ \\
\hline T0 ${ }^{1}$ & 387.4 & 16.82 & 68.35 & 527.4 & 26.87 & 1.021 & 2.117 \\
\hline $\mathrm{T} 1^{1}$ & 376.2 & 16.42 & 64.72 & 542.7 & 26.73 & 1.082 & 2.064 \\
\hline $\mathrm{T} 2^{1}$ & 355.4 & 15.77 & 60.74 & 568.1 & 26.29 & 1.199 & 2.059 \\
\hline T3 ${ }^{1}$ & 331.2 & 15.03 & 55.37 & 598.4 & 25.71 & 1.355 & 2.006 \\
\hline
\end{tabular}

Note: One-way analysis of variance (ANOVA) was used to determine the difference in the corn stalk composition. Multiple comparisons between every two treatments were performed using the least significant difference (LSD). Different lower-case letters in the same column mean significant difference at $p<0.05$ level; ${ }^{1}$ T0 was a control treatment of corn stalk without adding T. reesei; T1, T2, and T3 were three phases of fermented materials with T. reesei sampled in 2,4 , and 8 days, respectively.

\subsection{FTIR Spectra}

Through semi-quantitative analysis, it is known that the relative intensity of HAL at the peaks of $2920 \mathrm{~cm}^{-1}$ and $2850 \mathrm{~cm}^{-1}$ decreased, which indicate a great alleviation of vibration of polymethylene carbon and terminal carbon in aliphatic hydrocarbon; however, the relative intensities at the peaks of $1620 \mathrm{~cm}^{-1}$ and $1720 \mathrm{~cm}^{-1}$ decreased first and then raised up with time, indicating that fatty acids decreased while aromatic carbon and carboxyl content increased during the fermenting process. Several organic functional groups, such as $-\mathrm{COOH}$ in $1230 \mathrm{~cm}^{-1}$ and $\mathrm{Si}-\mathrm{O}$ in $1034 \mathrm{~cm}^{-1}$, were also found, but overlapped for impurities (Table 3 and Figure 2).

Table 3. HAL relative intensities of the main absorption peaks in FTIR spectrum.

\begin{tabular}{ccccccc}
\hline \multirow{2}{*}{ Treatment } & \multicolumn{3}{c}{ Relative Intensity (\%) } & \multicolumn{2}{c}{ Ratio } \\
\cline { 2 - 6 } & $\mathbf{2 9 2 0} \mathbf{~ c m}^{-1}$ & $\mathbf{2 8 5 0} \mathbf{~ c m}^{-1}$ & $\mathbf{1 7 2 0} \mathbf{~ c m}^{-1}$ & $\mathbf{1 6 2 0} \mathbf{~ c m}^{-1}$ & $\mathbf{2 9 2 0 / 1 7 2 0}$ & $\mathbf{2 9 2 0 / 1 6 2 0}$ \\
\hline T0 ${ }^{1}$ & $22.24 \mathrm{a}$ & $10.42 \mathrm{a}$ & $14.35 \mathrm{a}$ & $21.04 \mathrm{a}$ & $1.550 \mathrm{a}$ & $1.057 \mathrm{a}$ \\
$\mathrm{T}^{1}$ & $22.09 \mathrm{ab}$ & $9.630 \mathrm{~b}$ & $13.98 \mathrm{~b}$ & $12.62 \mathrm{~b}$ & $1.580 \mathrm{a}$ & $1.750 \mathrm{~b}$ \\
$\mathrm{~T}^{1}$ & $21.58 \mathrm{~b}$ & $7.210 \mathrm{c}$ & $16.91 \mathrm{c}$ & $15.62 \mathrm{c}$ & $1.276 \mathrm{~b}$ & $1.382 \mathrm{c}$ \\
$\mathrm{T}^{1}$ & $13.73 \mathrm{c}$ & $7.120 \mathrm{c}$ & $18.80 \mathrm{~d}$ & $22.96 \mathrm{~d}$ & $0.730 \mathrm{c}$ & $0.598 \mathrm{~d}$ \\
\hline
\end{tabular}

Note: One-way analysis of variance (ANOVA) was used to determine HAL differences in the relative intensities of the main absorption peaks of the FTIR spectrum. Multiple comparisons between every two treatments were performed using the least significant difference (LSD). Different lower-case letters in the same column mean significant difference at $p<0.05$ level; ${ }^{1} \mathrm{~T} 0$ was a control treatment of corn stalk without adding T. reesei; T1, T2, and $\mathrm{T} 3$ were three phases of fermented materials with $T$. reesei sampled in 2,4 , and 8 days, respectively.

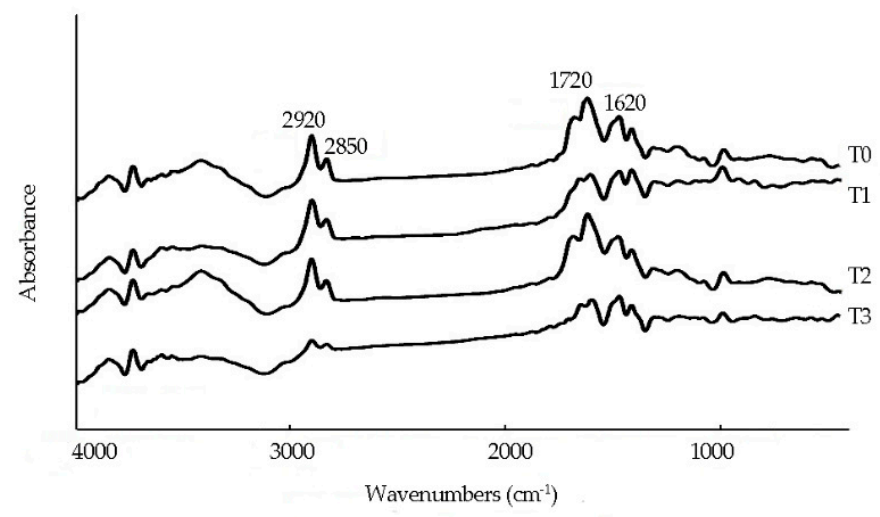

Figure 2. FTIR spectra of HAL in corn stalk. HAL represents substances that, like humic acid, are derived from fermented straw residue.

\subsection{HAL Thermal Stability}

To better understand HAL structural changes of corn stalk fermentation, HAL thermal stability and the corresponding mass change were accessed by DTA and TA. The thermal decomposition of samples 
was exothermic and divided into medium temperature phase $\left(270-362^{\circ} \mathrm{C}\right)$ and high temperature phase $\left(474-509^{\circ} \mathrm{C}\right.$ ) (Figure 3). Aliphatic pyrolysis occurred during the medium temperature phase; while in the high temperature phase, carboxyl and aromatic compounds were degraded under thermal action. There are two similar exothermic peaks between $\mathrm{T} 0$ and $\mathrm{T} 1$. The exothermic peak in $\mathrm{T} 2$ appeared at $270{ }^{\circ} \mathrm{C}$, which probably accounted for exothermic decarboxylation in the HAL peripheral functional group [29]. Further, T. reesei was prone to be active in this phase, suggesting that HAL composition was getting complex in the middle phase of degradation. The higher ratio of the heat released or the weight lost in the high temperature phase compared to that in the medium temperature phase means higher HAL thermal stability. In this experiment, both of the ratios were higher than that in T0 and increased with time, which suggested that the fermentation could increase the proportions of carboxyl and aromatic compounds and enhance the HAL thermal stability (Table 4).

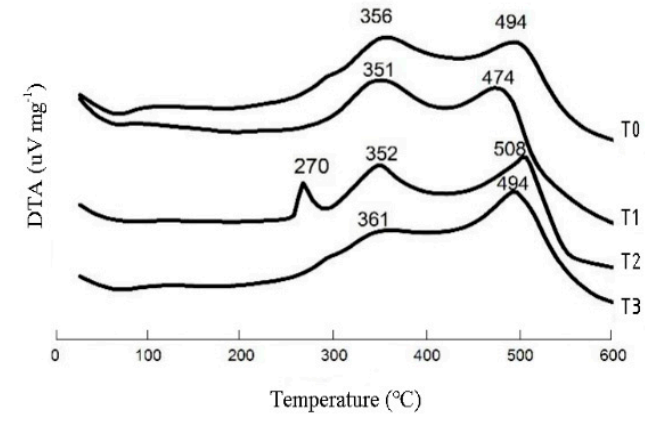

(a)

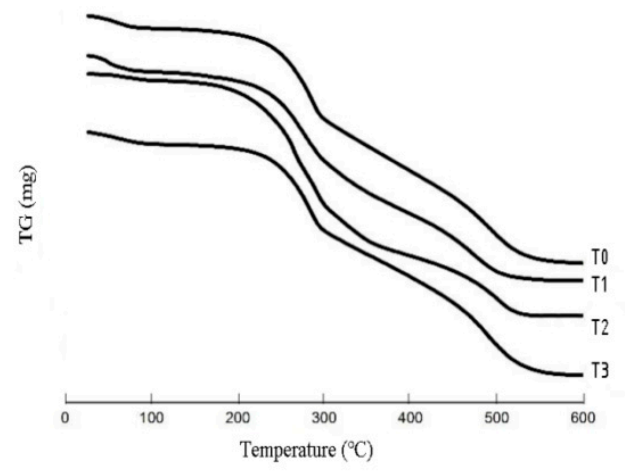

(b)

Figure 3. Thermal stability and change of corresponding mass of HAL. (a) Differential thermal analysis (DTA); (b) thermogravimetric analysis (TG). HAL represents substances that, like humic acid, were derived from fermented corn residue.

Table 4. Effects of T. reesei on exothermic heat and mass loss of HAL.

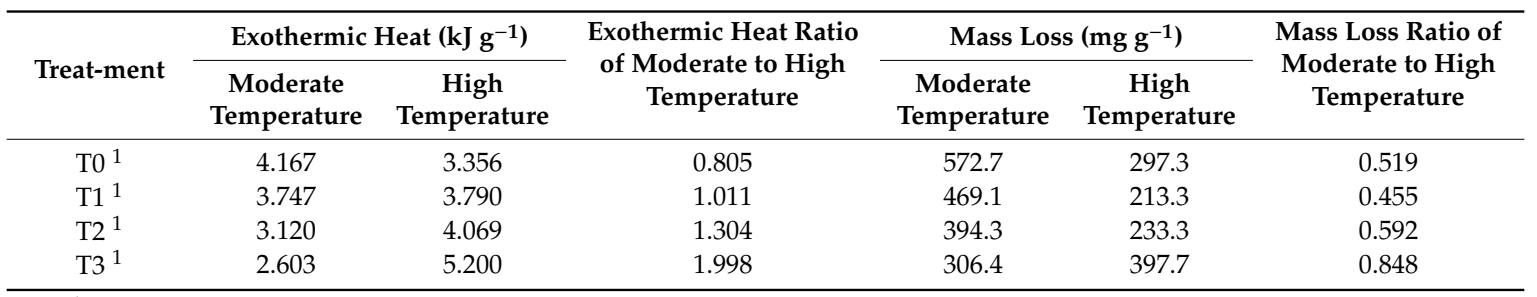

${ }^{1} \mathrm{~T} 0$ was a control treatment of corn stalk without adding T. reesei; $\mathrm{T} 1, \mathrm{~T} 2$, and T3 were three phases of fermented materials with $T$. reesei sampled in 2,4 , and 8 days, respectively.

\section{Discussion}

Weight and TOC content of corn stalk decreased during the eight days of fermentation. Both the cumulative degradation rates of lignin and cellulose increased more intensely in the last four days. Further, Pearson correlation analysis implied that the weight loss of corn stalk had a significantly positive correlation with TOC $(p<0.01)$, but TOC had a highly negative correlation with the degradation rate of lignin and cellulose $(p<0.01)$. Therefore, along with the weight loss of corn stalk, the easily degradable carbon was firstly exhausted, and then the hardly degradable material, including lignin and cellulose, was significantly decomposed. It was reported that cellulase activity reached the highest value in 77 hours, when the bagasse was degraded by T. reesei in solid-state fermentation [30]. Lee reported that cellulase activity reached the highest value at day five, when bagasse and palm meal were mixed in the ratio of 1:1 [31]. The present study suggests that the first several days are important for the enzyme activities of cellulase, xylanase, and $\beta$-glucosidase. The three enzymatic activities increased in the first four days, then decreased during the next four days. One possible reason might 
be T. reesei adapting to a new environment slowly in the early phase and alleviating the nutrients' limitations afterwards.

During the fermentation of corn stalk, T. reesei mainly produced: (i) cellulase, which cleaved glycosidic bonds and degraded cellulose to cellobiose; (ii) xylanase, which is a critical hydrolytic enzyme to hydrolyze xylan into oligosaccharides; and (iii) a small amount of xylose and arabinose [11]. At the final step of cellulose hydrolysis, $\beta$-glucosidase converted cellobiose to free glucose molecules. Thus, $\beta$-glucosidase showed comparatively higher enzyme activity $(88.91 \mathrm{IU} / \mathrm{mL})$ than the others on the fourth day, while xylanase had the lowest enzyme activity with $0.84 \mathrm{IU} / \mathrm{mL}$, as shown in Figure 1d,e.

According to Waxman's theory [32], lignin is the basic composition of humus. Lignin and its degradation products, such as phenolic compounds and aliphatic compounds, form humus-like materials. They are the important precursor materials of humus, and can further form humus through complex reaction mechanism. HULIS is mainly composed of HAL, FAL, and a comparatively large portion of HML, quantified by the content of organic carbon. The results present that the carbon content of FAL and HML decreased. However, both the carbon content of HAL and PQ values increased, indicating the fermentation process promoted the transformation of corn stalk residue to HAL. HAL concentration after eight days of corn stalk fermentation was higher than that of chicken manure compost $\left(\sim 52.0 \mathrm{~g} \cdot \mathrm{kg}^{-1}\right)$ [33], indicating that the addition of $T$. reesei to the fermentation process enhanced the degree of humification of corn stalk and the corn stalk fermentation product could be a good fertilizer. Part of the undecomposed corn stalks were transferred to HULIS under the action of microorganisms, in which part of the FAL and HML were either degraded or converted to HAL (Table 1, Table 3, and Figure 2). In general, $\mathrm{H} / \mathrm{C}$ ratio of HAL corn stalk was close to 2.0, making it higher than that of most soil, which is close to 1.0-1.2 [28]. Thus, it may indicate that HAL of corn stalk is not a similar substance with the precursor of humic acid. The fermentation process speeds the oxidation and aromatization of HAL, leading to a more complex molecular structure.

Compared to T0, aliphatic degree was greatly reduced in corn stalk under the fermentation of T. reesei, while the oxidation degree, condensation degree, and thermal stability significantly increased. The latter fact suggests that the structure of HAL tended to be complex with lignin decomposition. Yu et al. demonstrated that soil HA was prone to formation by converting reductive functional groups to oxidative functional groups during the process of straw decay [34]. Wang et al. indicated that HA was mainly derived from lignin in the early phase of formation. The final formation of HA needed a long period of soil humification [35]. Meanwhile, in a relatively short time, HAL has begun to form with a low aliphatic, high aromatic degree, and more complex macromolecular compounds through condensates and structural recombination processes.

\section{Conclusions}

The transformation efficacy from corn stalk to HULIS was studied based on the transform amount of HULIS associated with HAL changes in chemical composition and structure under the action of T. reesei. HAL and $P Q$ value increased $17.5 \%$ and $8.9 \%$, whereas substances of FAL and HML decreased $5.54 \%$ and $7.38 \%$, respectively, indicating that $T$. reesei promoted the transformation of corn stalk residues to HULIS during a short period of eight days, and part of the FAL and HML were degraded or converted to HAL. The highest decomposition rate of corn stalk and the highest activity of cellulase, xylanase, and $\beta$-glucosidase appeared at the fourth day. Additionally, the HAL degrees of condensation, oxidation, and aromatization, as well as HAL thermal stability, were improved, which indicated that T. reesei produced cellulase and promoted the transformation of corn stalk residues into stable HAL. Therefore, the corn stalk fermentation product could be a good fertilizer to improve soil characteristics, and the results also provide an available use of T. reesei in agricultural soil amelioration.

Author Contributions: Y.Y. set up and performed the experiments, and collected and analyzed data; L.W. contributed to method supervision and writing the manuscript preparation; K.S., Y.Z., and L.L. contributed to the experiment set up and by commenting on and editing the paper; X.S., X.L., and X.R., contributed to evaluating the 
data and editing the paper; S.D. contributed to designing the experiments and evaluating the data and editing the paper.

Funding: This work was financially supported by the National Natural Science Foundation of China (No.41571231, 41871210), the National Key Research and Development Program of China (No. 2016YFD0200304), and the Doctoral Research Program of Anhui University (No. Y040418036).

Acknowledgments: We would like to thank Shunli Wang (Chinese Academy of Agricultural Sciences) for linguistic assistance during the preparation of this manuscript.

Conflicts of Interest: The authors declare no conflict of interest.

\section{Abbreviations used in this paper:}

$\begin{array}{ll}\text { CSRE } & \text { corn stalk residue extract } \\ \text { DI } & \text { deionised } \\ \text { DNS } & \text { 3,5-dinitrosalicylic acid } \\ \text { DTA } & \text { differential thermal analysis } \\ \text { FAL } & \text { fulvic acid-like substance } \\ \text { FTIR } & \text { Fourier transform infrared spectrometer } \\ \text { HAL } & \text { humic acid-like substance } \\ \text { HML } & \text { humin-like substance } \\ \text { HULIS } & \text { humus-like substances } \\ \text { OD 540 } & \text { optical density at 540 nm } \\ \text { PQ } & \text { the percentage of HAL/[HAL + FAL] } \\ \text { TOC } & \text { total organic carbon } \\ \text { TG } & \text { thermogravimetric analysis }\end{array}$

\section{References}

1. Fushimi, A.; Saitoh, K.; Hayashi, K.; Ono, K.; Fujitani, Y.; Villalobos, A.M.; Shelton, B.R.; Takami, A.; Tanabe, K.; Schauer, J.J. Chemical characterization and oxidative potential of particles emitted from open burning of cereal straws and rice husk under flaming and smoldering conditions. Atmos. Environ. 2017, 163, 118-127. [CrossRef]

2. Delivand, M.K.; Barz, M.; Gheewala, S.H.; Sajjakulnukit, B. Economic feasibility assessment of rice straw utilization for electricity generating through combustion in Thailand. Appl. Energy 2011, 88, 3651-3658. [CrossRef]

3. Meena, S.; Navatha, S.; Devi, B.L.A.P.; Prasad, R.B.N.; Pandey, A.; Sukumaran, R.K. Evaluation of Amberlyst15 for hydrolysis of alkali pretreated rice straw and fermentation to ethanol. Biochem. Eng. J. 2015, 102, 49-53. [CrossRef]

4. Yang, J.; Liu, P.; Conrad, R. Response of fermenting bacterial and methanogenic archaeal communities in paddy soil to progressing rice straw degradation. Soil Biol. Biochem. 2018, 124, 70-80. [CrossRef]

5. Guan, R.; Li, X.; Wachemo, A.C.; Yuan, H.; Liu, Y.; Zou, D.; Zuo, X.; Gu, J. Enhancing anaerobic digestion performance and degradation of lignocellulosic components of rice straw by combined biological and chemical pretreatment. Sci. Total Environ. 2018, 637-638, 9-17. [CrossRef]

6. Brodeur, G.; Yau, E.; Badal, K.; Collier, J.; Ramachandran, K.B.; Ramakrishnan, S. Chemical and physicochemical pretreatment of lignocellulosic biomass: A review. Enzyme Res. 2011, 2011, 787532. [CrossRef]

7. Gong, W.; Zhang, H.; Liu, S.; Zhang, L.; Gao, P.; Chen, G.; Wang, L. Comparative Secretome Analysis of Aspergillus niger, Trichoderma reesei, and Penicillium oxalicum During Solid-State Fermentation. Appl. Biochem. Biotechnol. 2015, 177, 1252-1271. [CrossRef]

8. Glass, N.L.; Schmoll, M.; Cate, J.H.D.; Coradetti, S. Plant cell wall deconstruction by ascomycete fungi. Annu. Rev. Microbiol. 2013, 67, 477-498. [CrossRef]

9. Hu, Y.; Xue, H.; Liu, G.; Song, X.; Qu, Y. Efficient production and evaluation of lignocellulolytic enzymes using a constitutive protein expression system in Penicillium oxalicum. J. Ind. Microbiol. Biotechnol. 2015, 42, 877-887. [CrossRef] 
10. Adav, S.S.; Chao, L.T.; Sze, S.K. Quantitative secretomic analysis of Trichoderma reesei strains reveals enzymatic composition for lignocellulosic biomass degradation. Mol. Cell. Proteom. 2012, 11, M111-012419. [CrossRef]

11. Wen, Z.; Liao, W.; Chen, S. Production of cellulase/ $\beta$-glucosidase by the mixed fungi culture of Trichoderma reesei and Aspergillus phoenicis on dairy manure. Process Biochem. 2005, 40, 3087-3094. [CrossRef]

12. Zang, X.; Liu, M.; Wang, H.; Fan, Y.; Zhang, H.; Liu, J.; Xing, E.; Xu, X.; Li, H. The distribution of active $\beta$-glucosidase-producing microbial communities in composting. Can. J. Microbiol. 2017, 63, 998-1008. [CrossRef] [PubMed]

13. Xin, F.; Geng, A. Horticultural waste as the substrate for cellulase and hemicellulase production by Trichoderma reesei under solid-state fermentation. Appl. Biochem. Biotechnol. 2010, 162, 295-306. [CrossRef] [PubMed]

14. Sandhu, S.K.; Oberoi, H.S.; Babbar, N.; Miglani, K.; Chadha, B.S.; Nanda, D.K. Two-stage statistical medium optimization for augmented cellulase production via solid-state fermentation by newly isolated Aspergillus niger HN-1 and application of crude cellulase consortium in hydrolysis of rice straw. J. Agric. Food Chem. 2013, 61, 12653-12661. [CrossRef]

15. Sun, H.Y.; Ge, X.Y.; Hao, Z.K.; Ming, P. Cellulase production by Trichoderma sp. on apple pomace under solid state fermentation. Afr. J. Biotechnol. 2010, 9, 164-167. [CrossRef]

16. Maurya, D.P.; Singh, D.; Pratap, D.; Maurya, J.P. Optimization of solid state fermentation conditions for the production of cellulase by Trichoderma reesei. J. Environ. Biol. 2012, 33, 5-8. [CrossRef]

17. Awafo, V.A.; Chahal, D.S.; Simpson, B.K. Evaluation of combination treatments of sodium hydroxide and steam explosion for the production of cellulase-systems by two T. reesei mutants under solid-state fermentation conditions. Bioresour. Technol. 2000, 73, 235-245. [CrossRef]

18. Latifian, M.; Hamidi-Esfahani, Z.; Barzegar, M. Evaluation of culture conditions for cellulase production by two Trichoderma reesei mutants under solid-state fermentation conditions. Bioresour. Technol. 2007, 98, 3634-3637. [CrossRef]

19. Tan, J.; Xiang, P.; Zhou, X.; Duan, J.; Ma, Y.; He, K.; Cheng, Y.; Yu, J.; Querol, X. Chemical characterization of humic-like substances (HULIS) in PM 2.5 in Lanzhou, China. Sci. Total Environ. 2016, 573, 1481-1490. [CrossRef]

20. Trompowsky, P.M.; Benites, V.D.M.; Madari, B.E.; Pimenta, A.S.; Hockaday, W.C.; Hatcher, P.G. Characterization of humic like substances obtained by chemical oxidation of eucalyptus charcoal. Org. Geochem. 2005, 36, 1480-1489. [CrossRef]

21. Venturin, B.; Camargo, A.F.; Scapini, T.; Mulinari, J.; Bonatto, C.; Bazoti, S.; Siqueira, D.P.; Colla, L.M.; Jr, S.L.A.; Bender, J.P. Effect of pretreatments on corn stalk chemical properties for biogas production purposes. Bioresour. Technol. 2018, 266, 116-124. [CrossRef] [PubMed]

22. Ghose, T.K. Measurement of cellulase activities. Pure Appl. Chem. 1987, 59, 257-268. [CrossRef]

23. Bailey, M.J.; Biely, P.; Poutanen, K. Interlaboratory testing of methods for assay of xylanase activity. J. Biotechnol. 1992, 23, 257-270. [CrossRef]

24. Jabasingh, S.A.; Nachiyar, C.V. Response surface approach for the Biodegradation of pretreated coir pith using Aspergillus nidulans SU04 for cellulase production. In Proceedings of the International Conference on Sustainable Energy \& Intelligent Systems, Tamil Nadu, India, 20-22 July 2011. [CrossRef]

25. Kumada, K.; Sato, O.; Ohsumi, Y.; Ohta, S. Humus composition of mountain soils in Central Japan with special reference to the distribution of P type humic acid. Soil Sci. Plant Nutr. 1967, 13, 151-158. [CrossRef]

26. Zhang, Y.; Dou, S.; Ye, S.; Zhang, D. Specificity of humic acid-like (HAL) substance from Trichoderma reesei inoculated corn straw (In Chinese). J. Agro-Environ. Sci. 2019, 38, 2184-2192. [CrossRef]

27. Kuwatsuka, S.; Watanabe, A.; Itoh, K.; Arai, S. Comparison of two methods of preparation of humic and fulvic acids, IHSS method and NAGOYA method. Soil Sci. Plant Nutr. 2006, 38, 23-30. [CrossRef]

28. Dou, S. Soil Organic Matter; Science Press Co.: Beijing, China, 2010. (In Chinese)

29. Francioso, O.; Montecchio, D.; Gioacchini, P.; Cavani, L.; Ciavatta, C.; Trubetskoj, O.; Trubetskaya, O. Structural differences of Chernozem soil humic acids SEC-PAGE fractions revealed by thermal (TG-DTA) and spectroscopic (DRIFT) analyses. Geoderma 2009, 152, 264-268. [CrossRef]

30. Mekala, N.K.; Singhania, R.R.; Sukumaran, R.K.; Pandey, A. Cellulase Production Under Solid-State Fermentation by Trichoderma reesei RUT C30: Statistical Optimization of Process Parameters. Appl. Biochem. Biotechnol. 2008, 151, 122-131. [CrossRef] 
31. Lee, C.K.; Darah, I.; Ibrahim, C.O. Production and Optimization of Cellulase Enzyme Using Aspergillus niger USM AI 1 and Comparison with Trichoderma reesei via Solid State Fermentation System. Biotechnol. Res. Int. 2010, 2011, 658493. [CrossRef]

32. Sánchez, C. Lignocellulosic residues: Biodegradation and bioconversion by fungi. Biotechnol. Adv. 2009, 27, 185-194. [CrossRef]

33. Shi, M.; Wei, Z.; Wang, L.; Wu, J.; Zhang, D.; Wei, D.; Tang, Y.; Zhao, Y. Response of humic acid formation to elevated nitrate during chicken manure composting. Bioresour. Technol. 2018, 258, 390-394. [CrossRef] [PubMed]

34. Yu, X.; Tang, X.H.; Lv, J.; Luo, Y.; Wang, L.; Wei, C. Chemical Composition and Structure of Humic Acids from Decomposited Paddy Straw Residue. J. Soil Water Conserv. 2011, 1, 24. [CrossRef]

35. Wang, X.; Guan, W.; Yin, X. Dynamic change of chemical composition of corn straw and humic acid during different decomposition period II Change of humic acid properties and fractions. Agric. Reseach Arid Areas 2001, 19, 11-15. [CrossRef]

(C) 2019 by the authors. Licensee MDPI, Basel, Switzerland. This article is an open access article distributed under the terms and conditions of the Creative Commons Attribution (CC BY) license (http://creativecommons.org/licenses/by/4.0/). 